\title{
Ketahanan Hidup Bibit Ikan Mujair (Oreochromis mossambicus) dan Nilai Parameter Kimiawi Lingkungan Pada Media Pemeliharaan Bioflok dengan Debris Daluga Sebagai Sumber Karbon
}

\author{
Ferencia E. Rattu*, Emma M. Moko, Ernest H. Sakul, Orbanus Naharia, Aser \\ Yalindua, Livana Rawung
}

aProgram Studi Biologi, Universitas Negeri Manado, 95618, Indonesia

\begin{tabular}{l} 
I N F O A R T I K E L \\
\hline Diterima 17 Maret 2021 \\
Disetujui 29 April 2021 \\
\\
\hline Keyword: \\
Biofloc, \\
Tilapia, \\
Debris Daluga \\
\hline Kata kunci: \\
Bioflok, \\
Ikan Mujair, \\
Debris Daluga
\end{tabular}

*e-mail:emmamoko@unima.ac.id

\begin{abstract}
A B S T R A C T
Biofloc is a cultivation technique to manage aquaculture using microorganisms to increase feed and waste products by adding an organic carbon source. The purpose of this study is to determine the survival rate of tilapia (Oreochromis mossambicus) and the environmental chemical parameters in biofloc rearing media with daluga (Crytosperma merkusii) debris as a carbon source. This study used a completely randomized design (CRD) with four treatments and three replications. The treatments without biofloc as a control, $C: N=15, C: N=20$, and $C: N=25$. The mean length of Tilapia is $5.5 \mathrm{~cm}$ and spread ten fish per bucket. The research parameters are water quality and survival rate (SR)of Tilapia. The water quality parameters are including temperature, $\mathrm{pH}$, conductivity, and redox. The best treatment from the research results at $C: N=25$ with the highest SR percentage $86.67 \%$. The water quality during the research still in optimal conditions in every treatment.
\end{abstract}

A B S T R A K
Bioflok adalah teknik budidaya ikan untuk mengelola lingkungan budidaya
dengan memanfaatkan mikroorganisme untuk meningkatkan penggunaan
pakan dan sisa hasil metabolisme dengan penambahan sumber karbon
organik. Penelitian ini bertujuan untuk mengetahui ketahanan hidup bibit
ikan mujair (Oreochromis mossambicus) dan nilai parameter kimiawi
lingkungan pada media pemeliharaan bioflok dengan debris daluga
(Crytosperma merkusii) sebagai sumber karbon. Penelitian ini menggunakan
Rancangan Acak Lengkap (RAL) dengan 4 perlakuan dan 3 ulangan.
Perlakuan yang dilakukan adalah tanpa bioflok, C:N=15, C:N=20, dan
C:N=25. Hewan uji ikan mujair dengan panjang rata-rata 5,5 cm di tebar 10
ekor setiap ember. Parameter yang diamati adalah kualitas air yang meliputi
suhu, pH, konduktivitas, dan redoks dan Survival Rate (SR) ikan mujair. Dari
hasil penelitian diketahui bahwa perlakuan terbaik pada C: $\mathrm{N}=25$ dengan
persentase SR tertinggi yaitu, $86,67 \%$. Kualitas air selama penelitian ada pada
kondisi optimal di setiap perlakuan.

\section{Pendahuluan}

Ikan mujair (Oreochromis mossambicus) merupakan salah satu komoditas perairan tawar yang perkembangbiakannya relative lebih cepat dibandingkan dengan jenis ikan air tawar lainnya. Ikan mujair banyak terdapat di perairan Indonesia dan sering diolah menjadi sumber bahan makanan karena rasa dan kandungan proteinnya cukup tinggi sehingga ikan mujair banyak dibudidayakan oleh masyarakat [1-4]. Dalam pembudidayaan ikan mujair, masyarakat biasanya menggunakan pakan buatan. Namun, pakan buatan yang diberikan tidak semua dikonsumsi oleh ikan. Sehingga, pakan buatan tersebut terbuang dan mengganggu kualitas air dari ikan tersebut [5]. 
Tingginya penggunaan pakan dalam budidaya intensif, dapat mengakibatkan pencemaran lingkungan yang menyebabkan penyebaran penyakit. Ikan hanya menyerap $25 \%$ pakan yang diberikan, sedangkan $75 \%$ lainnya menjadi limbah di dalam air. Limbah dari pakan ini akan diubah oleh bakteri menjadi ammonia yang dapat menyebabkan kematian pada ikan [6].

Penerapan teknologi melalui pendekatan biologis, telah menerapkan teknik bioflok untuk menjaga kualitas air untuk budidaya [7]. Bioflok adalah teknik budidaya dengan rekayasa lingkungan menggunakan mikroorganisme dan oksigen untuk meningkatkan nilai cerna pakan. Teknologi bioflok menggunakan bakteri, jamur, plankton, alga yang mempengaruhi struktur nutrisi bioflok [8]. Penggunaan bioflok dapat membuat angka produktifitas panen lebih tinggi dibandingkan dengan nilai pertumbuhan ikan pada umumnya [9].

Prinsip teknik bioflok adalah potensial limbah dan konversi bioflok sebagai pakan alami dalam sistem pembudidayaan ikan dengan aerasi konstan. Penambahan sumber karbon sebagai substrat bahan organic memungkinkan dekomposisi aerobic dan mempertahankan tingkat mikroba flok dalam suspense pakan [5].

Talas rawa raksasa atau biasa dikenal oleh masyarakat lokal daluga adalah salah satu jenis tumbuhan talas-talasan yang banyak terdapat di Kabupaten Kepulauan Siau, Sangihe dan Talaud, Sulawesi Utara. Daluga sering dijadikan sebagai bahan makanan oleh masyarakat setempat. Hasil pengujian pati umbi daluga adalah sekitar $16-24 \%$, kadar lemak rendah $(<1 \%)$, dan mengandung lebih tinggi. Tingkat abu dan tingkat protein yang lebih rendah daripada pati sereal. Tepung daluga memiliki khasiat yang sama yaitu rendemen rata-rata $14,70 \%$ [10].

Penambahan sumber karbon dalam budidaya ikan dengan metode bioflok dapat memberikan pengaruh terhadap pertumbuhan ikan [11], oleh karena itu, dilakukan penelitian ini dengan tujuan untuk mengetahui ketahanan hidup ikan mujair dan nilai parameter kimiawi lingkungan pada media pemeliharaan dangan sistem bioflok menggunakan debris daluga sebagai sumber karbon.

\section{Bahan dan Metode}

Bahan yang digunakan dalam penelitian ini adalah air tawar, EM4, debris daluga, dan pakan. Ikan uji yang digunakan adalah ikan mujair dengan berat rata-rata ikan pada awal percobaan adalah $0,7 \mathrm{~g}$ per ekor sebanyak 120 ekor. Penelitian ini merupakan percobaan factorial yang diatur berdasarkan Rancangan Acak Lengkap (RAL) dengan 4 perlakuan dan 3 ulangan, sehingga total perlakuan ada 12 perlakuan. Perlakuan yang digunakan yaitu, perlakuan A sebagai Kontrol (Tanpa Bioflok), Perlakuan B dengan rasio C:N $=15$, perlakuan C dengan rasio $\mathrm{C}: \mathrm{N}=20$, dan perlakuan $\mathrm{D}$ dengan rasio $\mathrm{C}: \mathrm{N}=25$.

Wadah yang digunakan dalam kultur bioflok adalah 12 unit ember dan diisi dengan air tawar sebanyak 5L dan setelah itu diberi aerasi untuk mempertahankan oksigen terlarut. Setiap ember diisi 10 ekor ikan mujair. Bioflok diproduksi dengan menambahkan EM4 (Effective microorganisms-4) yang mengandung bakteri Lactobacillus casei dan Saccharomyces cerevisiae. Setiap 0,5mL EM4 dilarutkan ke dalam 5L air. Kemudian ditambahkan debris daluga dan diaduk hingga rata. Pemberian debris daluga disesuaikan dengan rasio yang telah ditentukan. Pemberian debris daluga dihitung berdasarkan rasio C:N seperti pada gambar 1 [12].

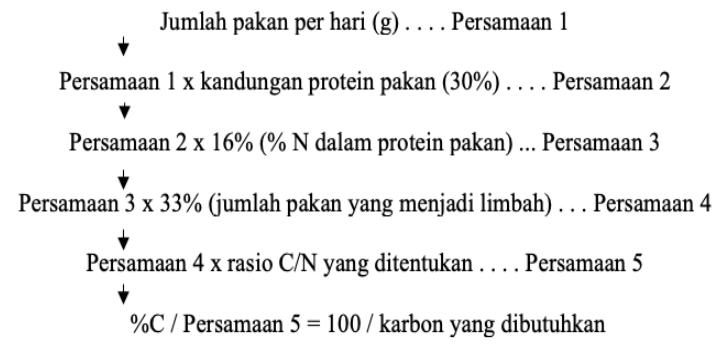

Gambar 1. Perhitungan debris daluga

Apabila jumlah pakan yang diberikan sebanyak 7,1g dengan kandungan protein 30\% dan kandungan karbon daluga adalah 37,86. Sehingga pemberian tepung daluga sebagai sumber karbon pada rasio C:N=15, C:N=20, dan $\mathrm{C}: \mathrm{N}=25$ secara berturut-turut adalah $4,49 \mathrm{~g}$, $5,94 \mathrm{~g}$, dan 7,42g. Pakan diberikan setiap hari sedangkan debris daluga diberikan seminggu 
sekali hingga akhir penelitian.

Parameter penelitian ikan mujair meliputi kualitas air dan survival rate. Kualitas air yang diamati meliputi suhu, $\mathrm{pH}$, konduktivitas, dan redoks. Data kualitas air didapati dengan menggunakan thermometer, $\mathrm{pH}$ meter, ORP meter, dan conductivity meter. Survival rate ikan dihitung dengan rumus persamaan 1. Data kualitas air yang diperoleh dianalisis secara deskriptif dan data hasil survival rate akan dianalisis menggunakan analisis ragam (ANOVA) dengan perangkat SPSS dengan taraf kepercayaan $95 \%$.

$$
\mathrm{SR}=\frac{N t}{N 0} \times 100 \%
$$

\section{Hasil dan Pembahasan}

Hasil pengukuran parameter kualitas air ikan mujair berupa suhu, $\mathrm{pH}$, conductivity, dan redoks disajikan dalam bentuk grafik setiap parameter pada tiap perlakuan serta persentase ketahanan hidup ikan mujair selama 15 hari pengamatan disajikan dalam tabel 1.

Suhu

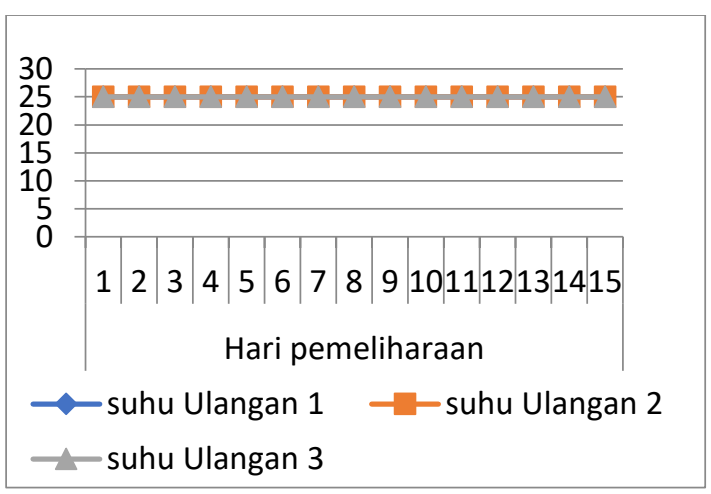

Gambar 2. Grafik Hasil Pengukuran Suhu Tanpa Bioflok

Pengukuran suhu air pemeliharaan ikan mujair menggukan conductivity meter. Hasil penelitian menunjukan suhu selama pemeliharaan ikan mujair adalah $25^{\circ} \mathrm{C}$ pada semua perlakuan dan ulangan. Hal ini terjadi karena lokasi penelitian berada ditempat yang sama sehingga suhu yang didapatkan sama, yaitu $25^{\circ} \mathrm{C}$. Ikan mujair dapat bertahan hidup pada kisaran suhu $14-38^{\circ} \mathrm{C}$ dengan suhu optimal untuk pertumbuhan dan pekembangannya adalah $25-30^{\circ} \mathrm{C}$ sehingga, suhu yang air selama masa pemeliharaan ikan mujair ini masih ada pada kondisi yang baik bagi ikan mujair seperti pada gambar 2, gambar 3, gambar 4, dan gambar 5 [13].

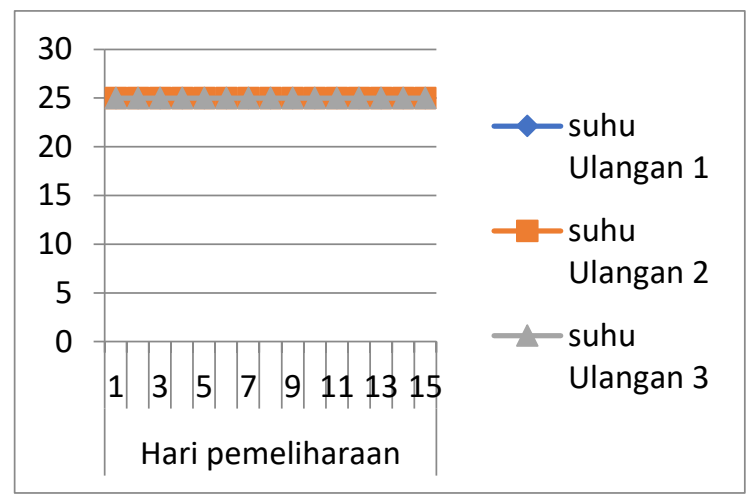

Gambar 3. Grafik hasil pengukuran suhu pada perlakuan $\mathrm{C}: \mathrm{N}=15$

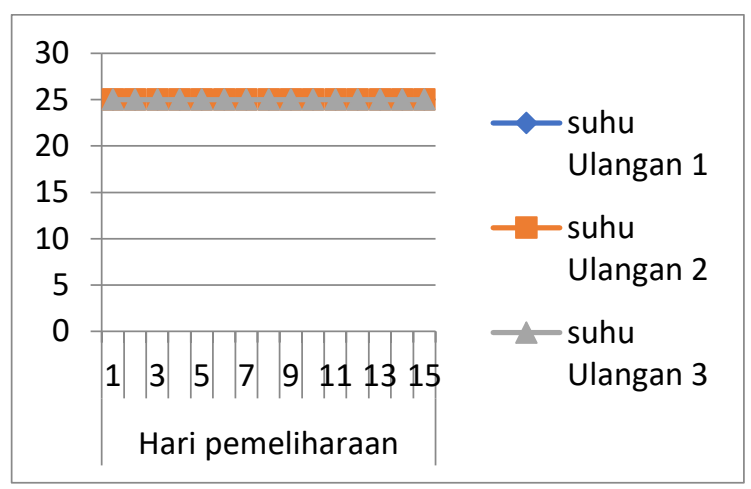

Gambar 4. Grafik hasil pengukuran suhu pada perlakuan $\mathrm{C}: \mathrm{N}=20$

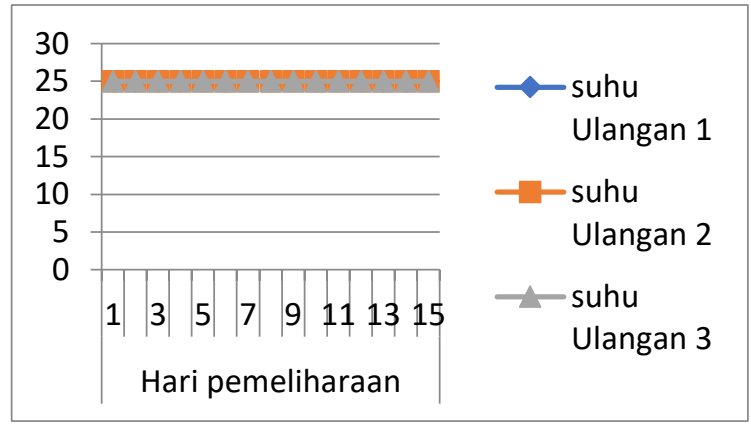

Gambar 5. Grafik hasil pengukuran suhu pada perlakuan $\mathrm{C}: \mathrm{N}=25$

Derajat Kasaman ( $p H)$

Pengukuran $\mathrm{pH}$ dilakukan setiap hari selama penelitian berlangsung. Dari data hasil penelitian, didapatkan bahwa $\mathrm{pH}$ air pemeliharaan ikan mujair tidak berbeda jauh antar tiap perlakuan dan ada pada kisaran 7,057,99 yang cukup stabil dan bisa menunjang pertumbuhan ikan mujair. Hasil $\mathrm{pH}$ pada setiap perlakuan menunjukan adanya penurunan $\mathrm{pH}$ 
dibanding hari pertama. Hal ini diduga karena adanya proses nitrifikasi pada media pemeliharaan dimana, bakteri nitrifikasi akan mereduksi amonia dan merubahnya menjadi nitrit dan nitrat yang tidak begitu toksik bagi pertumbuhan ikan mujair [14]. Namun, walau mengalami penurunan $\mathrm{pH}$ masih berada dalam batas toleransi optimum untuk pertumbuhan ikan, yaitu 7 - 8,5 untuk pertumbuhan ikan mujair [9]. Pada hari ke-8, pH setiap perlakuan ada pada kisaran 7,6-7,8 karena adanya pergantian air. $\mathrm{pH}$ perairan dipengaruhi oleh oksigen terlarut dimana semakin kecil oksigen terlarut kencenderungan $\mathrm{pH}$ akan bersifat basa dan sebaliknya sehingga berdasarkan hasil penelitian menunjukan bahwa, kondisi $\mathrm{pH}$ masih stabil pada angka 7 selama masa penelitian yang berarti konsentrasi oksigen terlarut juga relatif stabil seperti yang terlihat pada gambar 6, gambar 7, gambar 8, gambar 9 [15].

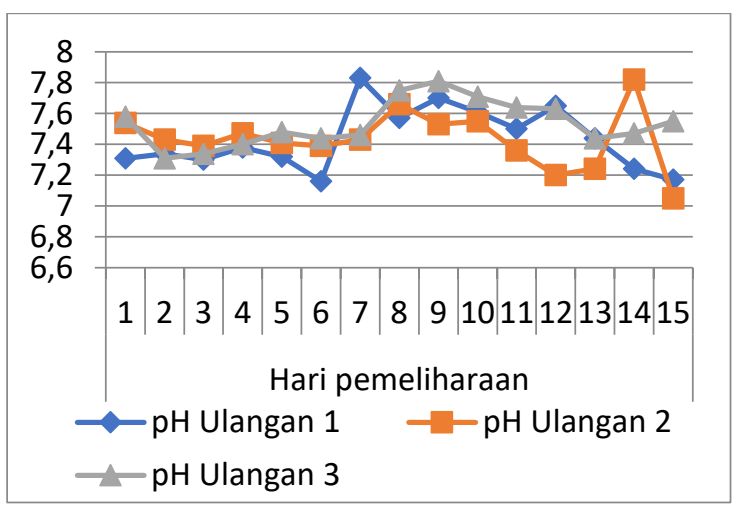

Gambar 6. Grafik hasil pengukuran $\mathrm{pH}$ pada perlakuan tanpa bioflok

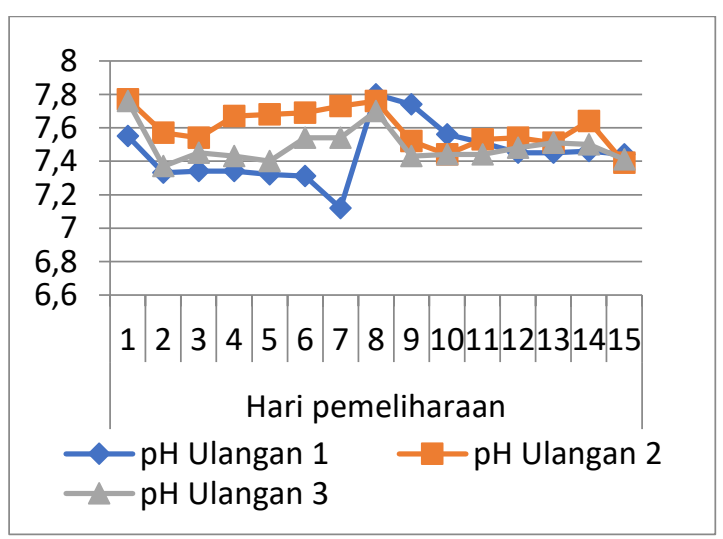

Gambar 7. Grafik hasil pengukuran $\mathrm{pH}$ pada perlakuan C:N=15

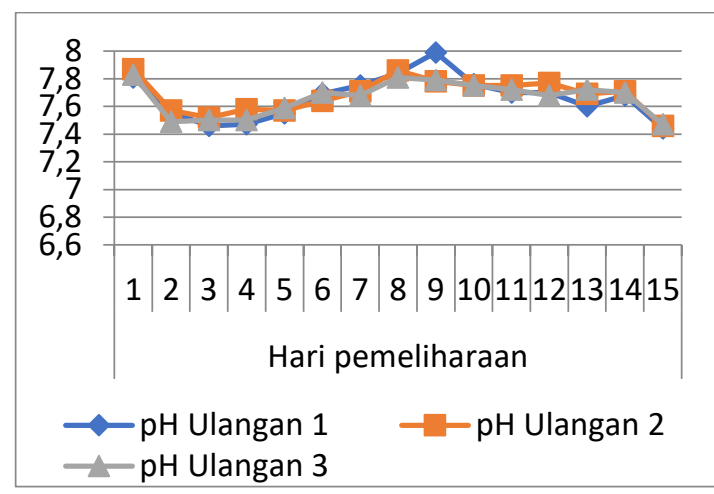

Gambar 8. Grafik hasil pengukuran $\mathrm{pH}$ pada perlakuan $\mathrm{C}: \mathrm{N}=20$

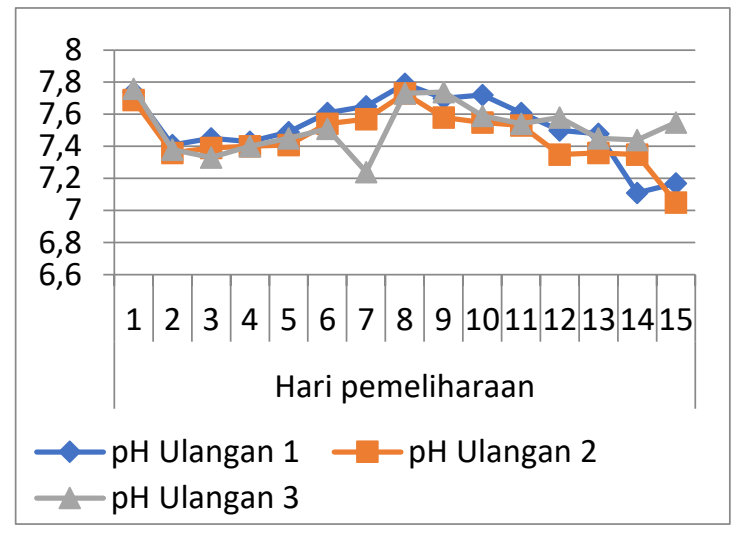

Gambar 9. Grafik hasil pengukuran $\mathrm{pH}$ pada perlakuan C:N=25

\section{Konduktifitas Air}

Konduktivitas air adalah kemampuan air untuk mengetahui daya hantar listrik (DHL). Daya hantar listrik ini diukur pada suhu standart yaitu pada $25^{\circ} \mathrm{C}$. Konduktivitas air bergantung pada jumlah ion-ion terlarut per volumenya dan mobilitas ion-ion tersebut. Secara umum, faktor yang lebih dominan dalam perubahan konduktivitas air adalah temperatur. Nilai konduktivitas air tawar adalah $<650 \mu \mathrm{S} / \mathrm{cm}$ [16], kondisi air dalam kisaran perairan alami adalah $20-1500 \mu \mathrm{S} / \mathrm{cm}$. Semakin tinggi nilai konduktivitas di perairan menunjukkan adanya bahan pencemar yang masuk.

Berdasarkan gambar 10, gambar 11, gambar 12, dan gambar 13 hasil pengukuran konduktivitas air selama penelitian tidak berbeda jauh antar tiap perlakuan dan masih berada pada kisaran normal yaitu, 485-908 $\mu \mathrm{S} / \mathrm{cm}$. Nilai tertinggi konduktivitas berada pada hari ke-7 disetiap ulangan yang mengindikasikan bahan pencemar didalam air 
semakin meningkat dan dilakukan penggantian air pada hari ke-8 untuk mengurangi bahan pencemar di dalam air yang dapat berbahaya bagi ikan. Pada hari ke-15 di dapati bahwa ratarata nilai konduktivitas pada perlakuan tanpa bioflok tetap naik sedangkan pada perlakuan dengan bioflok terjadi penurunan. Hal ini mengindikasikan semakin tingginya kandungan bahan pencemar pada perlakuan tanpa biofllok karena tidak ada bakteri yang dapat mengasimilasi sisa pakan dan feses ikan yang dapat mencemari air.

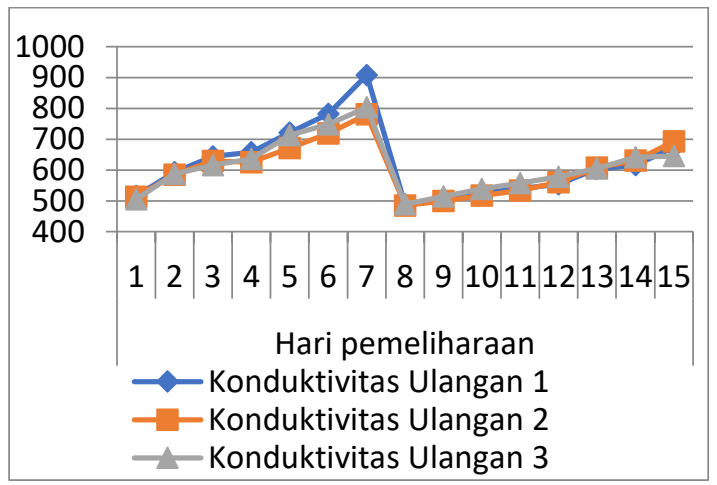

Gambar 10. Grafik hasil pengukuran konduktifitas pada perlakuan tanpa bioflok

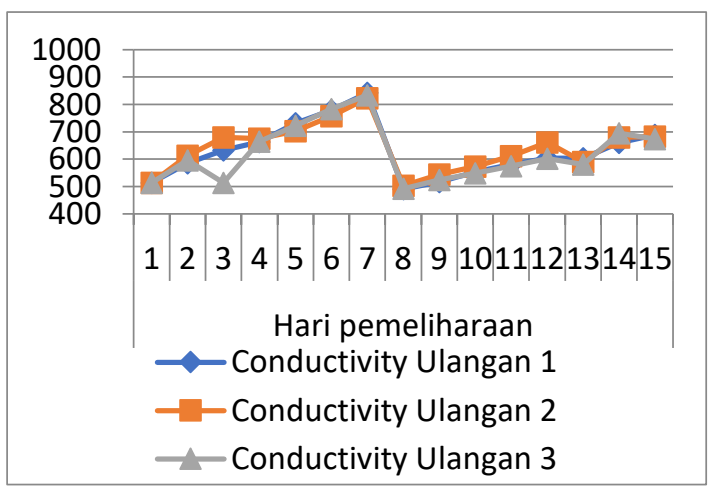

Gambar 11. Grafik hasil pengukuran konduktifitas pada perlakuan $\mathrm{C}: \mathrm{N}=15$

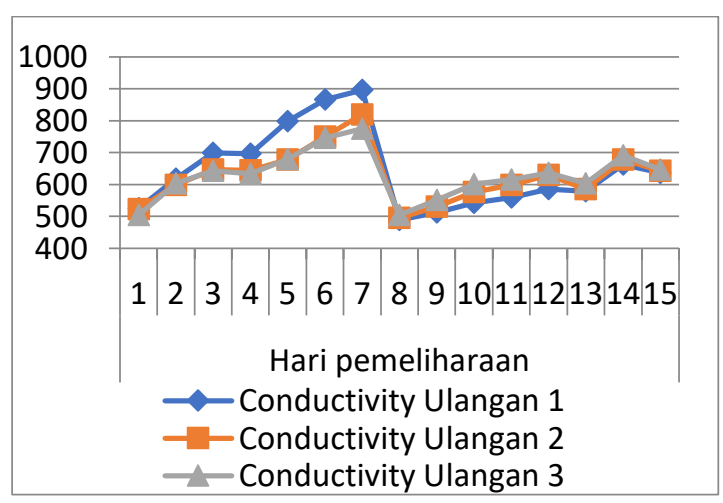

Gambar 12. Grafik hasil pengukuran konduktifitas pada perlakuan $\mathrm{C}: \mathrm{N}=20$

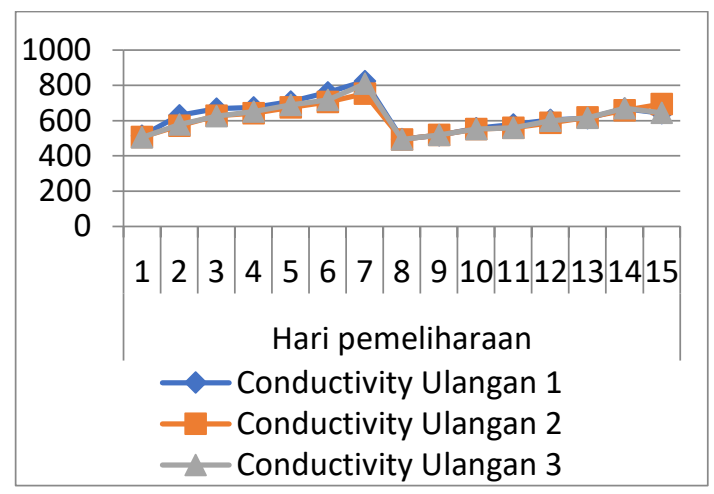

Gambar 13. Grafik hasil pengukuran konduktifitas pada perlakuan C:N=25

Redoks

Reaksi redoks terdiri dari dua reaksi, yaitu reaksi reduksi dan reaksi oksidasi. Reaksi reduksi adalah reaksi pelepasan oksigen, sedangkan oksidasiadalah reaksi pengikatan oksigen. Didalam air, kondisi redoks terjadi apabila jika oksigen menurun maka, terjadi proses denitrifikasi. Dalam penelitian nilai redoks air pemeliharaan ikan mujair, nilai redoks berkisar 479-717.

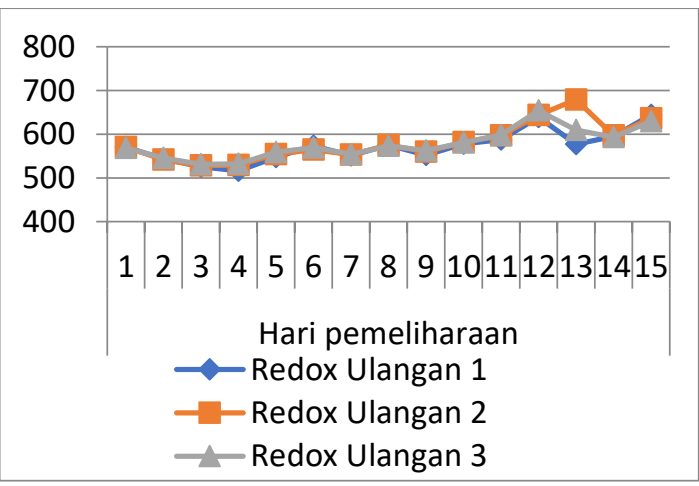

Gambar 14. Grafik hasil pengukuran redoks pada perlakuan tanpa bioflok

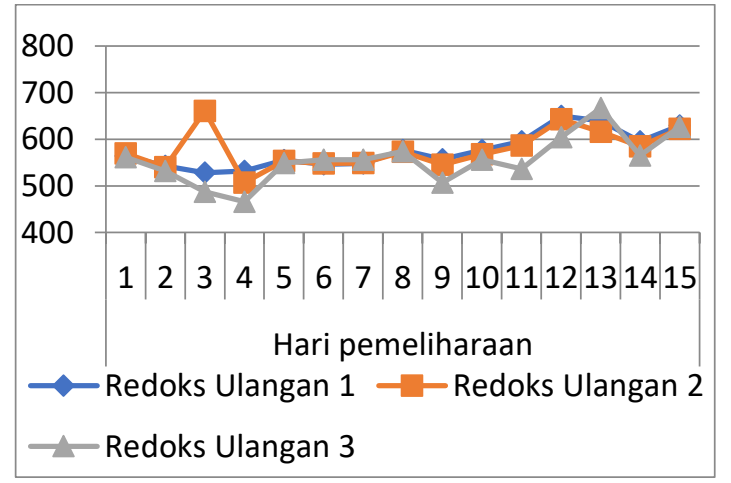

Gambar 15. Grafik hasil pengukuran redoks pada perlakuan $\mathrm{C}: \mathrm{N}=15$ 
Nilai yang lebih besar menunjukkan kondisi yang lebih teroksidasi [17]. Berdasarkan grafik pada gambar 14, gambar 15, gambar 16 dan gambar 17 tidak ada perbedaan yang nyata antar setiap perlakuan namun, nilai redoks masih ada pada kondisi yang normal untuk pemeliharaan ikan.

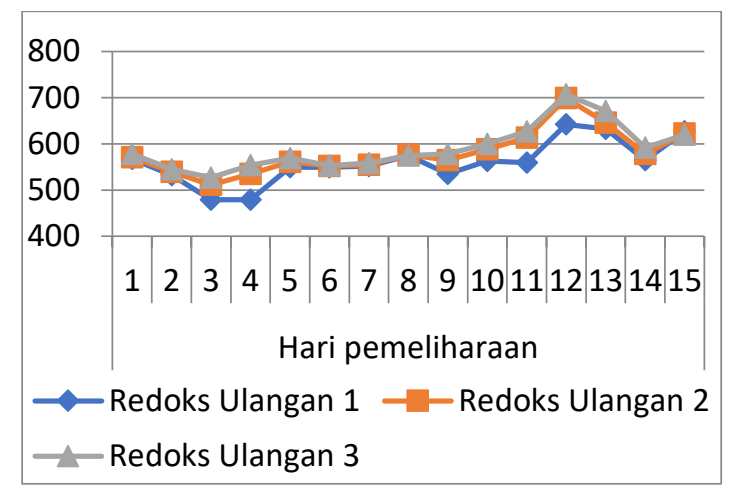

Gambar 16. Grafik hasil pengukuran redoks pada perlakuan C: $\mathrm{N}=20$

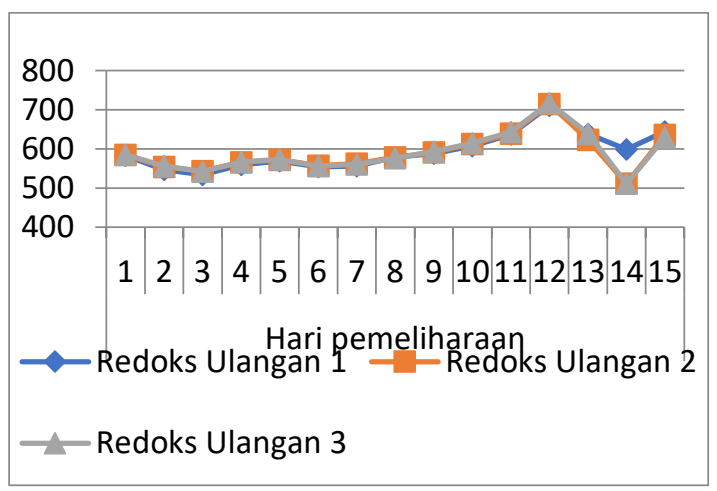

Gambar 17. Grafik hasil pengukuran redoks pada perlakuan C: $\mathrm{N}=25$

Konsentrasi oksigen terlarut adalah faktor yang penting dalam mempengaruhi proses dan kondisi air dan sedimen dalam budidaya ikan. Kebutuhan oksigen dalam budidaya ikan tergantung pada difusi oksigen pada bagian atas air. Pada kedalaman 0-4cm, ketika kandungan oksigen menurun, terjadi proses denitrifikasi [17].

\section{Survival Rate (SR)}

Data hasil uji ANOVA berdasarkan hasil SR ikan mujair dengan tambahan probiotik dan debris daluga disajikan dalam tabel 1. Hasil penelitian menunjukkan bahwa budidaya ikan mujair dengan kultur bioflok memiliki perbedaan nyata $(\mathrm{P}<0,05)$ yaitu, nilai sig. ada pada angka 0,001. Rata-rata persentase nilai SR dari perlakuan tanpa bioflok, C:N=15 ulangan 1,2, dan 3 berturut-turut adalah 1,9 mg, 1,8 mg, dan 2,2 mg. Untuk C:N=20 ulangan 1,2, dan 3 berturut-turut adalah 10,8 mg, 11,7 mg dan 9,9 mg, sedangkan untuk C:N=25 ulangan 1, 2, dan 3 secara berturut-turut adalah 11,4 mg, 11,7 mg, dan $12,3 \mathrm{mg}$.

Tabel 1. Data hasil uji ANOVA

\begin{tabular}{lccccc}
\hline \multicolumn{5}{c}{ ANOVA } \\
Survival Rate \\
\hline & $\begin{array}{l}\text { Sum of } \\
\text { Squares }\end{array}$ & df & $\begin{array}{l}\text { Mean } \\
\text { Square }\end{array}$ & F & Sig. \\
\hline $\begin{array}{l}\text { Between } \\
\text { Groups } \\
\text { Within }\end{array}$ & 6825.000 & 3 & 2275.000 & 14.368 & .001 \\
Groups & 1266.667 & 8 & 158.333 & & \\
Total & 8091.667 & 11 & & & \\
\hline
\end{tabular}

Penggunaan debris daluga yang paling baik ada pada perlakuan $\mathrm{C}: \mathrm{N}=25$ karena memiliki rata-rata nilai persentase paling tinggi dan perlakuan tanpa bioflok memiliki nilai paling rendah. Pemberian probiotik dan debris daluga dianggap cukup efisien karena memberikan hasil SR yang baik. Hal ini membuktikan bahwa pemeliharaan ikan menggunakan kultur bioflok memiliki tingkat ketahanan hidup ikan menjadi lebih tinggi dibandingkan dengan cara konvensional.

Tingginya angka kematian ikan pada perlakuan tanpa bioflok bisa diakibatkan oleh rendahnya kualitas air. Hal ini disebabkan karena tidak adanya mikroorganisme yang dapat mengurai pakan dan sisa metabolisme ikan sehingga, semua material tersebut terakumulasi dan mengendap dalam wadah dalam konsentrasi yang tinggi. Material tersebut terurai dan membentuk substrat yang bersifat racun [9]. Kondisi ini menyebabkan ikan menjadi stress dan berkurangnya nafsu makan sehingga menyebabkan kematian pada ikan sehingga kultur bioflok dapat mereduksi senyawa berbahaya di dalam air yang menyebabkan nafsu makan ikan lebih banyak. Hal ini dibuktikan dengan pakan yang selalu habis pada setiap pemberian.

Kualitas air manjadi faktor utama yang mempengaruhi sistem imun ikan dan 
meminimalisir angka kematian ikan mujair. Dari data hasil penelitian yang didapatkan, ikan tanpa kultur bioflok memiliki nilai SR yang lebih rendah dibandingkan dengan ikan dengan kultur bioflok. Hal ini disebabkan oleh adanya bakteri heterotrof yang mampu mengasimilasikan ammonia menjadi protein [12]. Penerapan sistem bioflok dapat mereduksi senyawa-senyawa organic pakan dan sisa hasil metabolisme ikan yang dapat menurunkan kualitas air yang bersifat toksin bagi ikan [15]. Berdasarkan data kualitas air, diketahui tidak ada perbedaan yang nyata antar setiap perlakuan. Ini diduga karena jumlah ikan didalam wadah lebih sedikit yang menyebabkan sisa pakan dan sisa hasil metabolisme ikan juga sedikit sehingga, tidak ada perbedaan nyata antar setiap perlakuan.

Kematian pada perlakuan tanpa bioflok banyak terjadi, diduga karena hasil metabolisme yang dikeluarkan berupa karbondioksida dan amonia yang terakumulasi di dalam air. Amonia telah terkumpul didalam air akan sangat berbahaya dan dapat memicu timbulnya racun yang dapat menyebabkan kematian pada benih ikan. Sementara, nilai SR paling baik ada pada perlakuan $\mathrm{C}: \mathrm{N}=25$. Hal ini diduga karena semakin banyak konsentrasi debris daluga yang diberikan maka, pembentukan flok akan semakin baik [12].

Dari data hasil penelitian menunjukkan bahwa semakin tinggi konsentrasi debris daluga yang diberikan, nilai SR semakin tinggi. Hal ini diduga karena adanya bakteri heterotrof yang dapat bekerja lebih optimal dengan pemberian debris daluga sebagai sumber karbon. Dengan adanya debris daluga, bakteri dapat mengubah karbon dan nitrogen anorganik menjadi sumber pakan alami bagi ikan sehingga, efisiensi pakan dapat lebih tinggi.

\section{Ucapan terima kasih}

Ucapan terima kasih kami pada pimpinan Balai Ikan di Tondano yang sudah mengijinkan penulis untuk melaksanakan penelitian.

\section{Kesimpulan}

Penggunaan kultur bioflok dapat memberikan pengaruh terhadap pemeliharaan ikan mujair. Kualitas air selama penelitian juga ada pada keadaan yang optimal. Penggunaan rasio C:N dapat memberikan pengaruh yang nyata terhadap nilai SR ikan mujair. Rasio C:N yang paling baik adalah $\mathrm{C}: \mathrm{N}=25$ dengan ratarata nilai SR tertinggi.

\section{Daftar Pustaka}

1. Trilaksani, W.; Riyanto, B.; Susanto, H. Pemanfaatan Protein Ikan Mujair (Oreochromis Mossambicus Peters.) Sebagai Bahan Baku Pembuatan Fish Cake Goreng. Jurnal Pengolahan Hasil Perikanan Indonesia 2004, 7.

2. Sumiati, T. Pengaruh Pengolahan Terhadap Mutu Cerna Protein Ikan Mujair (Tilapia Mossambica). Program Studi Gizi Masyarakat dan Sumberdaya Keluarga, Fakultas Pertanian. Institut Pertanian Bogor, Bogor 2008.

3. Hartono, G.S. Utilization of Fish Protein Concentrate of Tilapia Fish (Oreochromis Mossambicus) on Baby Biscuit= Pemanfaatan Konsentrat Protein Ikan Mujair (Oreochromis Mossambicus) Dalam Pembuatan Biskuit Bayi. PhD Thesis, Universitas Pelita Harapan, 2011.

4. Ariyani, F.; Saleh, M.; Tazwir, T.; Hak, N. Optimasi Proses Produks I Htdroltsat Protein Ikan (Hpi) Dari Mujair (Oreochromrb Mossambicusl. Jurnal penelitian perikanan Indonesia 2017, 9, 11-21.

5. Muhammad, J.; Yusminah, H. Identifikasi Perifiton Sebagai Penentu Kualitas Air Pada Tambak Ikan Nila (Oreochromis Niloticus). bionature 2013, 14.

6. Imron, A.; Sudaryono, A.; Harwanto, D. Pengaruh Rasio C/N Berbeda Terhadap Rasio Konversi Pakan Dan Pertumbuhan Benih Lele (Clarias Sp.) Dalam Media Bioflok. Journal Of Aquaculture Management And Technology 2014, 3, 17-25.

7. Suharyatun, S.S.; Amin, M.; Waluyo, S. Pemberdayaan Masyarakat Kecamatan Pagelaran Pringsewu, Sebagai Kawasan Minapolitan. Batoboh 2018, 3, 67-82.

8. Adharani, N.; Soewardi, K.; Syakti, A.D.; Hariyadi, S. Manajemen Kualitas Air Dengan Teknologi Bioflok: Studi Kasus Pemeliharan Ikan Lele (Clarias Sp.). Jurnal Ilmu Pertanian Indonesia 2016, 21, 35-40.

9. Ombong, F.; Salindeho, I.R. Aplikasi 
Teknologi Bioflok (BFT) Pada Kultur Ikan Nila, Orechromis Niloticus. e-Journal Budidaya Perairan 2016, 4.

10. Limbe, H.W.; Achmadi, S.S.; Faridah, D.N. Introducing Daluga (Cyrtosperma Merkusii) Starch from Corms Collected in Siau Island, North Sulawesi. In Proceedings of the IOP Conference Series: Earth and Environmental Science; IOP Publishing, 2019; Vol. 399, p. 012038.

11. Pramono, T.B.; Sukardi, P.; Soedibya, P.H.T. Produksi Budidaya Ikan Nila (Oreochromis Niloticus) Sistem Bioflok Dengan Sumber Karbohidrat Berbeda. Asian Journal of Innovation and Entrepreneurship 2018, 3, 198-203.

12. Runa, N.M. Pemanfaatan Tepung Tapioka Dengan Dosis Berbeda Sebagai Sumber Karbon Pembentuk Bioflok Pada Media Pemeliharaan Benih Ikan Patin (Pangasius Sp.). Journal of Aquaculture and Fish Health 2019, 8, 54-61.

13. Karim, M.F.; Abidin, Z.; Ilmi, U. Prototipe monitoring kadar keasaman air, suhu air dan pemberian pakan otomatis pada tambak ikan mujair berbasis mikrokontroller. SinarFe7 2020, 3, 41-46.

14. Yuniasari, D. Pengaruh Pemberian Bakteri Nitrifikasi Dan Denitrifikasi Serta Molasedengan C/N Rasio Berbeda Terhadap Profil Kualitas Air, Kelangsungan Hidup, Dan Pertumbuhan Udang Vaname (Litopenaeus Vannamei). Institut Pertanian Bogor. Bogor 2009.

15. Azhari, D.; Tomasoa, A.M. Kajian Kualitas Air Dan Pertumbuhan Ikan Nila (Oreochromis Niloticus) Yang Dibudidayakan Dengan Sistem Akuaponik. Akuatika Indonesia 2018, 3, 8490.

16. Marasabessy, U.R.; La Goa, Y.; Pristianto, H. Pedoman Praktikum Pengelolaan Kualitas Air Prodi Teknik Sipil UM Sorong. 2018.

17. Gunarto, G. Apakah nilai reduksi dan oksidasi potensial sedimen tambak berpengaruh terhadap produksi udang windu di tambak. Media Akuakultur 2006, 1, 91-96.

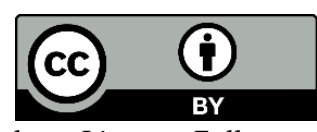

(C) 2021 by the authors. Licensee Fullerene Journal Of Chem. This article is an open access article distributed under the terms and conditions of the Creative Commons Attribution (CC BY) license

(http://creativecommons.org/licenses/by/4.0/). 